\title{
Abstract withdrawn
}

From 15th International Conference on Human Retroviruses: HTLV and Related Viruses

\section{Abstract withdrawn}

Abstract has been withdrawn

Published: 6 June 2011

doi:10.1186/1742-4690-8-S1-A243

Cite this article as: : Abstract withdrawn. Retrovirology 2011 8(Suppl 1):

A243.

Submit your next manuscript to BioMed Central and take full advantage of:

- Convenient online submission

- Thorough peer review

- No space constraints or color figure charges

- Immediate publication on acceptance

- Inclusion in PubMed, CAS, Scopus and Google Scholar

- Research which is freely available for redistribution 